\title{
EVALUATION OF POTENCY OF KNOWN OXIMES (PRALIDOXIME, TRIMEDOXIME, HI-6, METHOXIME, OBIDOXIME) TO IN VITRO REACTIVATE ACETYLCHOLINESTERASE INHIBITED BY PESTICIDES (CHLORPYRIFOS AND METHYLCHLORPYRIFOS) AND NERVE AGENT (RUSSIAN VX)
}

\author{
Kamil Musílek ${ }^{1,3}$, Kamil Kuča ${ }^{1,2}$, Daniel Jun ${ }^{1,2}$ \\ University of Defence, Faculty of Military Health Sciences, Hradec Králové, Czech Republic: Department of Toxicology ${ }^{1}$, \\ Centre of Advanced Studies²; Charles University in Prague, Faculty of Pharmacy in Hradec Králové, Czech Republic: \\ Department of Pharmaceutical Chemistry and Drug Control ${ }^{3}$
}

Summary: Nerve agents and pesticides belong to the group of organophosphates. They are able to inhibit irreversibly the enzyme acetylcholinesterase (AChE). Acetylcholinesterase reactivators were designed for the treatment of nerve agent intoxications. Their potency to reactivate pesticide-inhibited AChE was many times evaluated. In this study, five commonly used AChE reactivators (pralidoxime, methoxime, HI-6, obidoxime, trimedoxime) for the reactivation of AChE inhibited by two pesticides (chlorpyrifos and methylchlorpyrifos) were used. Russian VX (nerve agent) as a member of nerve agents' family was taken for comparison. Obtained results show that oximes developed against nerve agent intoxication are less effective for intoxication with organophosphorus pesticides. Especially, methylchlorpyrifos-inhibited AChE was found to be poorly reactivated by the compounds used.

Key words: Organophosphate; Nerve agent; Pesticide; Acetylcholinesterase; Reactivation; In vitro

\section{Introduction}

Organophosphate compounds (OPC) are well known as substances developed in the past for military purposes (nerve agents - e.g. tabun - GA, Russian VX - RVX or VX). At present, they are widely spread as pesticides in agriculture (e.g. chlorpyrifos - CPF, methylchlorpyrifos - MCPF, parathion - PTH) as potential therapeutics in medicine or used for various purposes in the industry (Fig. 1) $(1,12$ ).

These compounds inhibit irreversibly the enzyme acetylcholinesterase (AChE, EC 3.1.1.7). Their toxic effect is based on phosphorylation of the enzyme active site, where they are covalently bounded on serine hydroxyl group (Scheme 1) (1,2).

The inhibition of AChE leads to over-stimulation of muscarinic and nicotinic receptors due to the excess of acetylcholine at the synaptic clefts. This excess gives rise to the cholinergic crisis with typical symptoms (miosis, lacrimation, salivation, convulsions, etc.). Further, the depression of breathing centre occur and cause the death by ventilation failure (1).

The threat of the intoxications by these compounds rapidly increases with growing agricultural production and in relationship with the threat of terrorist attacks (3). The effective antidotes used to counteract the effects of OPC intoxications are oxime reactivators able to break the bond inhibitor-AChE and restore the enzyme activity (1). Frequently used AChE reactivators are pralidoxime (2-PAM, 2-hydroxyiminomethyl-1-methylpyridinium chloride), tri-<smiles>COP(=S)(OC)Oc1nc(Cl)c(Cl)cc1Cl</smiles>

Scheme 1: Methylchlorpyrifos-inhibited AChE. 
medoxime (TMB-4, 1,3-bis(4-hydroxyiminomethylpyridinium)propane dibromide), obidoxime (Toxogonin ${ }^{\circledR}, 1,3-$ bis $(4$ hydroxyiminomethylpyridinium)-2-oxapropane dichloride), HI-6 (1-(2-hydroxyiminomethylpyridinium)-3-(4-carbamoylpyridinium)-2-oxapropane dichloride) and methoxime (MMC, bis(4-hydroxyiminomethylpyridinium)methane dichloride) (Fig. 2) (4). The reactivators are combined with atropine sulphate to suppress the cholinergic symptoms (16-17).

However, no one of the above mentioned reactivators is able to satisfactorily reactivate $\mathrm{AChE}$ inhibited by various types of OPC (11). Therefore, the development and selection of new effective reactivators of $\mathrm{AChE}$ used as antidotes for OPC poisoning are very important due to the extended usage of pesticides in agriculture and subsequent potential human intoxications. Especially, pesticides are known as compounds with low response on the treatment with reactivators developed for nerve agent intoxication (18-19). Accordingly, this work was focused on testing in vitro of activity of five currently used AChE reactivators against pesticide in vitro. Thus, we wanted to compare their reactivation potency with that obtained for Russian VX.<smiles>COP(C)(=S)Oc1nc(Cl)c(Cl)cc1Cl</smiles>

methylchlorpyrifos (MCPF)<smiles>CCOP(=S)(OCC)Oc1nc(Cl)c(Cl)cc1Cl</smiles>

chlorpyrifos (CPF)<smiles>CCOP(=S)(OCC)Oc1ccc([N+](=O)[O-])cc1</smiles>

parathion $(\mathrm{PTH})$<smiles>CCOP(=O)(C#N)N(C)CC</smiles>

tabun (GA)<smiles>CCN(CC)CCCCC(C)C</smiles>

Russian VX (RVX)<smiles>CCOP(C)(=O)[Si]CN(C)C(C)C</smiles>

VX

Fig. 1: Structural formulae of organophosphate compounds.<smiles></smiles>

2-PAM<smiles>O=Nc1cc[n+](CO)cc1</smiles>

obidoxime<smiles>O=Cc1cc[n+](C[n+]2ccc(C=NO)cc2)cc1</smiles>

MMC

Fig. 2: Structural formulae of frequently used acetylcholinesterase reactivators.<smiles></smiles>

TMB-4<smiles></smiles>

HI-6

$$
2 \mathrm{Cl}^{\ominus}
$$




\section{Materials and methods}

The AChE reactivators used in this study were previously synthesized at the Department of Toxicology of the Faculty of Military Health Sciences in Hradec Kralove (Czech Republic). Their reactivation activity was tested in vitro on OPC-inhibited $\mathrm{AChE}$ using a modification of standard reactivation test ( 8$)$. The rat brain homogenate $(10 \%$ in distilled water) was used as a source of AChE.

The brain homogenate $(0.5 \mathrm{ml})$ was mixed with $20 \mu \mathrm{l}$ of isopropanol solution of OPC (to achieve $95 \%$ inhibition of $\mathrm{AChE}$ ) and incubated at $25^{\circ} \mathrm{C}$ for 30 minutes. $2.5 \mathrm{ml}$ of solution of sodium chloride $(3 \mathrm{M})$ were added to the mixture and filled to the volume $23 \mathrm{ml}$ with distilled water. Finally, $2 \mathrm{ml}$ of solution of acetylcholine iodide $(0.02 \mathrm{M})$ were added. The enzyme activity was measured at $\mathrm{pH} 7.6$ and temperature $25^{\circ} \mathrm{C}$ on autotitrator RTS 822 (Radiometer, Denmark). Activities of intact $\operatorname{AChE}\left(\mathrm{a}_{0}\right)$ and inhibited $\operatorname{AChE}\left(\mathrm{a}_{\mathrm{i}}\right)$ were deducted from influence of consumption of $\mathrm{NaOH}$ solution $(0.01 \mathrm{M})$ on time. After the incubation of AChE with OPC ( 30 minutes), the reactivator was added to the solution and the mixture was incubated for 10 minutes. Activity of reactivated $\mathrm{AChE}\left(\mathrm{a}_{\mathrm{r}}\right)$ was also computed from influence of consumption of $\mathrm{NaOH}$ solution on time.

The percentage of reactivation (\%) was calculated from measured data according to formula:

$$
x=\left(1-\frac{a_{r}-a_{i}}{a_{0}-a_{i}}\right) \cdot 100 \quad[\%]
$$

Each measurement was repeated three times and standard deviations were calculated.

\section{Results and discussion}

The relationship between concentration and reactivation efficacies of studied reactivators is shown in Fig. 3 and Fig. 4.

The reactivation potency necessary for proper effect during intoxication should exceed $10 \%$ (1). As it can be seen (Fig. 3-4), not all compounds are able to surpass this limit for various OPC. The results for both concentrations are satisfactory for CPF and RVX with exception of pralidoxime and trimedoxime at $10^{-5} \mathrm{M}$. On the other hand, there is almost no reactivation response at the concentration $10^{-5} \mathrm{M}$ for AChE inhibited by pesticide MCPF.

The concentration of reactivator plays also important role in the reactivation process. The concentration $10^{-3} \mathrm{M}$ is not attainable for in vivo experiments (16). From this point of view, there are some reactivators suitable at $10^{-5} \mathrm{M}$ for special type of OPC (obidoxime and trimedoxime for CPF; methoxime and HI-6 for RVX) and due to this also applicable for human use. However, there is not compound usable for in vivo experiments in case of MCPF poisoning. The small change of molecule of CPF to MCPF (Fig. 1) leads to different compound's properties during inhibition of AChE. The data are not available in literature and this finding should be more investigated.
The structural factors of $\mathrm{AChE}$ reactivators appropriate for each OPC could be recommended. Generally for the molecule of reactivator, a quaternary heteroaromatic ring, an oxime moiety and a connecting bridge are necessary (11). All these structural factors are each to other dependent. The quaternary nitrogen is fundamental for affinity to the enzyme's cavity. All tested compounds contain at least once quaternary nitrogen. The presence of oxime group in its dissociated form (oximate anion) is essential for own reactivation (8). The position of oxime on heteroaromatic ring influences the activity of the compound (13-15). The position four (obidoxime, trimedoxime, methoxime) is more proper for $\operatorname{CPF}$ and $\operatorname{RVX}(9,14)$. On the other hand, the position two (HI-6) has better results for RVX at lower concentration $10^{-5} \mathrm{M}$ (10). Furthermore, the shorter connecting chain (methoxime) is superior to others in reactivation of RVX (Fig. 3) (6). The three- (obidoxime, trimedoxime, HI-6) or four-atom (K074) linker is convenient to the most of tested OPC (CPF, RVX) (5-6, 9, 15). However, the structural factors appropriate for MCPF-inhibited AChE can not be defined from the obtained data because of low activity of tested reactivators.

In conclusion, the results show that reactivators invented for military purposes (for nerve agents) are not effective for all pesticide-inhibited AChE. Due to this fact, it is necessary to prepare new broad-spectrum reactivators effective both for nerve agents and pesticides.

\section{Acknowledgements}

The authors express their appreciation to Mrs. M. Hrabinová for her technical assistance. The work was supported by the grant of Grant Agency of Ministry of Education, Youth and Sports (Czech Republic) - project No. ME865.

\section{References}

1. Bajgar J. Organophosphates/nerve agent poisoning: mechanism of action, diagnosis, prophylaxis, and treatment. Adv Clin Chem 2004;38:151-216.

2. Ekstrom F, Akfur C, Tunemalm K, Lundberg S. Structural changes of phenylalanine 338 and histidine 447 revealed by the crystal structures of tabun-inhibited murine acetylcholinesterase. Biochemistry. 2006;45:74-81.

3. Gupta R. Toxicology of organophosphate \& carbamate compounds. In: Global epidemiology of organophosphate and carbamate poisonings. Elsevier Academic Press, London, pp. 89-102.

4. Kassa J. Review of oximes in the antidotal treatment of poisoning by organophosphorus nerve agents. J Toxicol Clin Toxicol. 2002;40:803-816.

5. Kassa J, Kuča K, Cabal J. Comparison of the efficacy of currently available oximes against tabun in rats. Biologia 2005;60:79-81

6. Kuča K, Patočka J, Cabal J. Reactivation of organophosphate inhibited acetylcholinesterase activity by $\alpha, \omega$-bis-(4-hydroxyiminomethylpyridinium)alkanes in vitro. J Appl Biomed. 2003;1:207-11.

7. Kuča K, Pícha J, Cabal J, Liška F. Synthesis of the three monopyridinium oximes and evaluation of their potency to reactivate acetylcholinesterase inhibited by nerve agents. J Appl Biomed. 2004;2:51-56.

8. Kuča K, Cabal J. Evaluation of newly synthesized reactivators of the brain cholinesterase inhibited by sarin-nerve agent. Toxicol Mech Method. 2005;15: 247-52

9. Kuča K, Cabal J, Musílek K, Jun D, Bajgar J. Effective bisquaternary reactivators of tabun-inhibited AChE. J Appl Toxicol. 2005;25:491-5.

10. Kuča K, Cabal J, Jun D, Kassa J, Bartošová L, Kunešová G. In vitro reactivation potency of some acetylcholinesterase reactivators against sarin- and cyclosarin-induced inhibitions. J Appl Toxicol. 2005;25:296-300. 
11. Kuča K, Jun D, Musílek K. Structural requirements of acetylcholinesterase reactivators. Mini-Rev Med Chem. 2006;6:269-77.

12. Marrs TC. Organophosphate poisoning. Pharmacol Ther. 1993;58:51-66

13. Musílek K, Kuča K, Jun D, Dohnal V. Doležal M. Synthesis of a novel series of bispyridinium compounds bearing a xylene linker and evaluation of their reactivation activity against chlorpyrifos-inhibited acetylcholinesterase. J Enzym Inhib Med. Chem. 2005;20:409-15

14. Musílek K, Kuča K, Jun D, Dohnal V, Doležal M. Synthesis of the novel series of bispyridinium compounds bearing (E)-but-2-ene linker and evaluation of their reactivation activity against chlorpyrifos-inhibited acetylcholinesterase. Bioorg Med Chem Lett. 2006;16:622-7.

15. Musílek K., Lipka L., Račáková V., Kuča K., Jun D., Dohnal V., Doležal M. New methods in synthesis of acetylcholinesterase reactivators and evaluation of their potency to reactivate cyclosarin-inhibited AChE. Chem Pap. 2006;60:48-51.

16. Tattersall JE. Ion channel blockade by oximes and recovery of diaphragm muscle from soman poisoning in vitro. Br J Pharmacol. 1993;108:1006-15.

17. Taylor P. Anticholinergic agents. In: The Pharmacological Basis of Therapeutics. 2001; Hill, New York, pp. 175-91.

18. Thiermann H, Szinicz L, Eyer F, Worek F, Eyer P, Felgenhauer N, Zilker T Modern strategies in therapy of organophosphate poisoning. Toxicol Lett. 1999; 107:233-9.

19. Worek F, Thiermann H, Szinicz L, Eyer P. Kinetic analysis of interactions between human acetylcholinesterase, structurally different organophosphorus compounds and oximes. Biochem Pharmacol. 2004;68:2237-48.

Submitted March 2007. Accepted July 2007.

\section{Corresponding author:}

Ing. Kamil Kuča Ph.D., University of Defence, Faculty of Military Health Sciences, Třebešská 1575, 50001 Hradec Králové, Czech Republic, kucakam@seznam.cz 